\title{
Static Load Test and Numerical Analysis of Influencing Factors of the Ultimate Bearing Capacity of PHC Pipe Piles in Multilayer Soil
}

\author{
Xusen $\mathrm{Li}^{1,2}{ }^{1,}$ Jiaqiang Zhang ${ }^{3}$, Hao Xu ${ }^{4}$, Zhenwu Shi ${ }^{1}$ and Qingfei Gao ${ }^{3, *}$ (D) \\ 1 School of Civil Engineering, Northeast Forestry University, Harbin 150040, China; lixusen@nefu.edu.cn (X.L.); \\ shizhenwu@nefu.edu.cn (Z.S.) \\ 2 Heilongjiang Provincial Longjian Road and Bridge the First Engineering Co., Ltd., Harbin 150028, China \\ 3 School of Transportation Science and Engineering, Harbin Institute of Technology, Harbin 150090, China; \\ 20S132064@stu.hit.edu.cn \\ 4 Heilongjiang Transportation Investment Engineering Construction Co., Ltd., Harbin 150040, China; \\ xuhao@hljsjt.com.cn \\ * Correspondence: gaoqingfei@hit.edu.cn; Tel.: +86-137-0361-6436
}

Citation: Li, X.; Zhang, J.; Xu, H.; Shi, Z.; Gao, Q. Static Load Test and Numerical Analysis of Influencing Factors of the Ultimate Bearing Capacity of PHC Pipe Piles in Multilayer Soil. Sustainability 2021, 13, 13166. https://doi.org/10.3390/ su132313166

Academic Editor: Gianluca Mazzucco

Received: 14 September 2021

Accepted: 25 November 2021

Published: 27 November 2021

Publisher's Note: MDPI stays neutral with regard to jurisdictional claims in published maps and institutional affiliations.

Copyright: (c) 2021 by the authors. Licensee MDPI, Basel, Switzerland. This article is an open access article distributed under the terms and conditions of the Creative Commons Attribution (CC BY) license (https:/ / creativecommons.org/licenses/by/ $4.0 /)$.

\begin{abstract}
Prestressed high-strength concrete (PHC) pipe piles have been widely used in engineering fields in recent years; however, the influencing factors of their ultimate bearing capacity (UBC) in multilayer soil need to be further studied. In this paper, a static load test (SLT) and numerical analysis are performed to obtain the load transfer and key UBC factors of pipe piles. The results show that the UBC of the test pile is mainly provided by the pile shaft resistance (PSR), but the pile tip resistance (PTR) cannot be ignored. Many factors can change the UBC of pipe piles, but their effects are different. The UBC of the pipe pile is linearly related to the friction coefficient and the outer-to-inner diameter ratio. Changes in the pile length make the UBC increase sharply. Low temperatures can produce freezing stress at the pile-soil interface. The effect of changing the Young modulus of pile tip soil is relatively small.
\end{abstract}

Keywords: PHC pipe pile; ultimate bearing capacity; static load test; load transfer; multiple factor analysis

\section{Introduction}

Pile foundations have the advantages of a high bearing capacity, small settlement, convenient construction, strong resistance to complex loads and great applicability to various geological conditions [1,2]. They have been widely used in bridge engineering in China, accounting for more than $40 \%$ of the total number of bridge foundations [3]. As a new form of pile, a prestressed high-strength concrete (PHC) pipe pile adopts the assembly construction method, which has the advantages of high industrialization, easy quality assurance, short manufacturing cycles and low resources; it has been popularized on a large scale in recent years [4]. However, the practice of utilizing PHC pipe piles is not based on theory; experience is considered more important than the relevant science and technology, therefore, the wide use of PHC pipe piles at large scales does not fully utilize advanced technology. In the process of their popularization and application, there are still many theoretical and technical problems that need to be studied in depth [5], such as how to determine the ultimate bearing capacity (UBC) of pipe piles, the deviation of piles, the poor shear capacity caused by prefabrication and assembly, the floating of piles and their buckling instability [6-9].

Among them, the UBC, as the most critical factor affecting the use of pipe piles, has gradually become a research hotspot in recent years. Malik [10] and Abu-Farsakh [11] found that the bearing capacity of pipe piles is superior to that of other piles under the same conditions. Paik [12] and Saleem [13] suggested that the method of pipe pile installation 
is the key point affecting the bearing capacity. Some scholars have conducted SLTs on pipe piles to obtain the UBC of pipe piles, comparing the results with those from the existing calculation theory, and modifying the relevant formulas [14-16]. Soil plugs on the interior of pipe piles produce additional friction, which improves the UBC to a certain extent and has also been studied by many scholars [17-20]. The variations in pile bearing capacity with service time [21,22] and different soil conditions [23-25] have also received extensive attention.

However, to date, research on the UBC of pipe piles has been conducted in mostly single-layer soil; few studies have been conducted in multilayer soil $[11,25,26]$. In addition, most of the previous studies focused on testing. Although the test process can represent the actual performance of the pipe pile, it is complex, time-consuming and expensive; thus, it is currently impossible to conduct a more comprehensive analysis on the influencing factors of the UBC of pipe piles. Thus, the load transfer and key UBC factors of pipe piles in multilayer soil cannot be suitably studied. In this paper, first, we conduct a static load test (SLT) to obtain the load transfer of the pipe pile in multilayer soil. Second, we establish a pile-soil interaction model to explore the key factors affecting the UBC of pipe piles. Then, we summarize the results, supplement the research on the UBC of pipe piles in multilayer soil and provide a theoretical basis for further engineering applications of pipe piles.

\section{Project Overview}

In the Harbin to Zhaoyuan expressway project, a K50 + 230.5 vehicular overpass with good transportation conditions was selected for the pilot project of the pile SLT. The span of the $\mathrm{K} 50+230.5$ vehicle overpass was $30+40+30=100 \mathrm{~m}$. The superstructure of the bridge consisted of three prestressed concrete small box girders, and the bridge width was $8.5 \mathrm{~m}$. The substructure adopted PHC pipe piles. The left abutment foundation pile was selected as the test pile; it was made of C 80 concrete, with a pile length of $36 \mathrm{~m}$. Its section size and reinforcement are shown in Figure 1.

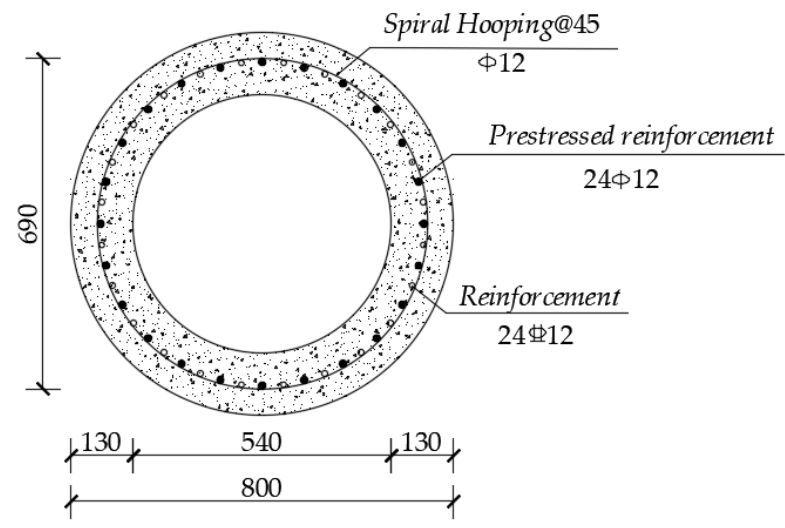

Figure 1. Section size and reinforcement of the pipe pile.

According to the drilling data, the physical and mechanical properties of the foundation soil where the test pile was located are shown in Table 1.

Table 1. Physical and mechanical properties of foundation soil.

\begin{tabular}{|c|c|c|c|c|c|}
\hline Name & $\begin{array}{l}\text { Thickness } \\
\text { (m) }\end{array}$ & $\begin{array}{l}\text { Density } \\
\left(\mathrm{kg} / \mathrm{m}^{3}\right)\end{array}$ & Internal Friction Angle $\left({ }^{\circ}\right)$ & Cohesion Force (kPa) & $\begin{array}{c}\text { Young's } \\
\text { Modulus (MPa) }\end{array}$ \\
\hline Silty clay & 12.7 & 1800 & 25 & 10 & 40 \\
\hline Coarse grit & 2.5 & 1950 & 33 & 2 & 42 \\
\hline $\begin{array}{l}\text { Weathered } \\
\text { sandstone }\end{array}$ & 6.7 & 1900 & 32 & 50 & 50 \\
\hline Mudstone & 14.1 & 2500 & 37 & 150 & 2000 \\
\hline
\end{tabular}




\section{Static Load Test}

\subsection{Test Loading Device}

The test method used here was the slow maintenance load method, and a kentledge device was used for loading. The counterforce device consisted of a counterforce beam, four secondary beams, a jack and weight, its general layout is shown in Figure 2.

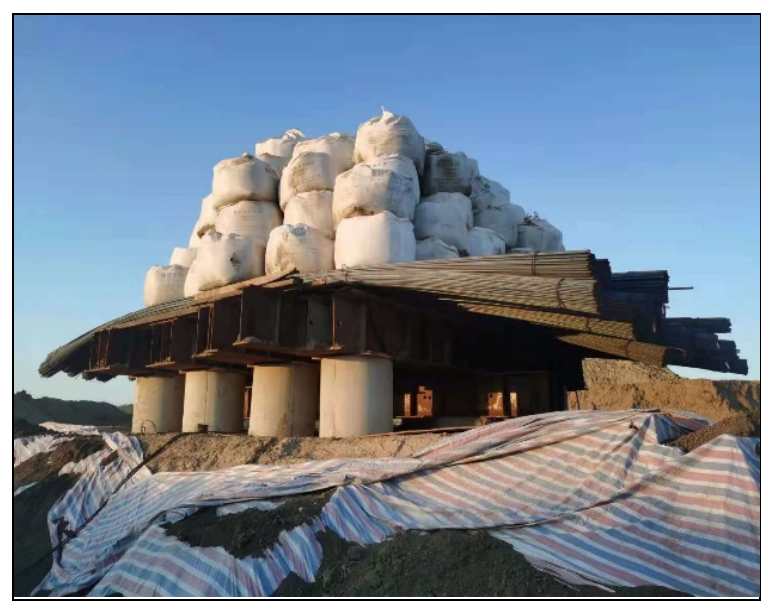

Figure 2. General layout of the test.

\subsubsection{Counterforce Beam and Secondary Beam}

The counterforce beam and secondary beam formed a steel structure with a length of $8 \mathrm{~m}$ and three spliced I-shaped sections. Ten concrete round piers were poured around the test pile to support the counterforce beam and secondary beams. The concrete round pier was a C30 plain concrete structure, with a pier diameter of $1.0 \mathrm{~m}$ and a pier height of $1.0 \mathrm{~m}$. The center distance between the concrete round pier and the test pile was $2.55 \mathrm{~m}$, and the layout is shown in Figure 3.

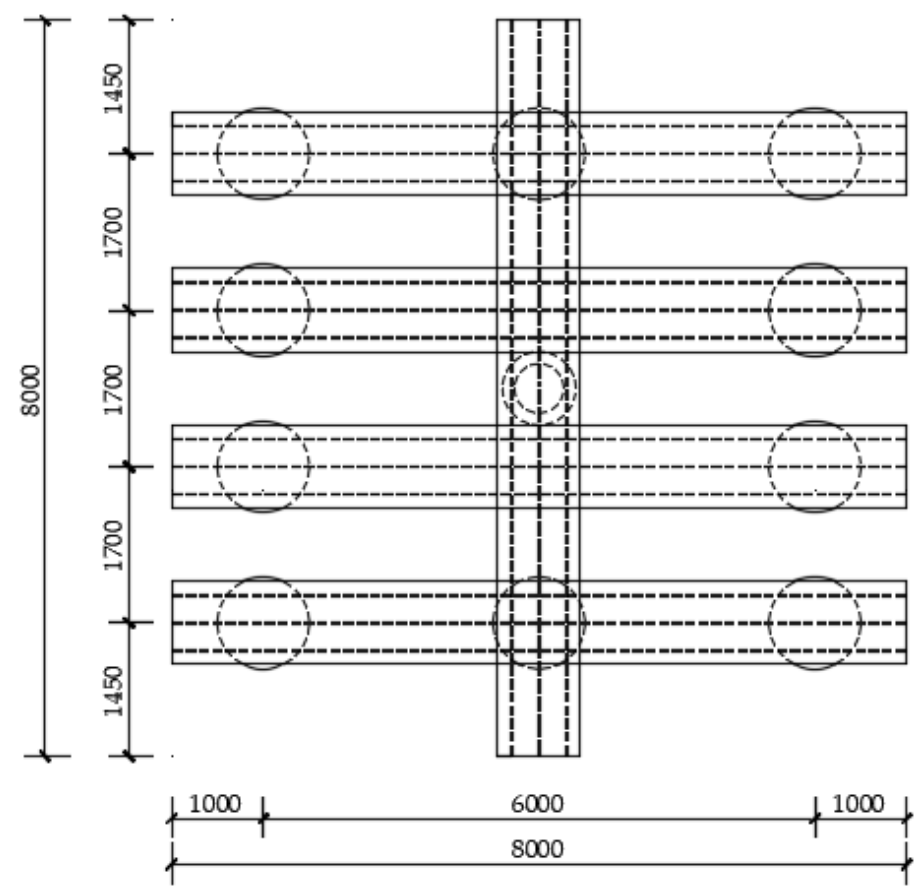

Figure 3. Layout of the counterforce beam and secondary beam. 


\subsubsection{Hydraulic Jack and Weight}

A 400-ton hydraulic jack was used for loading; the jack was connected to an oil pump through an oil distribution pipe, and the counterforce of the jack was borne by the weight. The materials used for the weight were HRB400 reinforcement and soil bags used in the project, and the total mass of the weight was required to be slightly greater than the maximum load grade. The jack arrangement is shown in Figure 4.

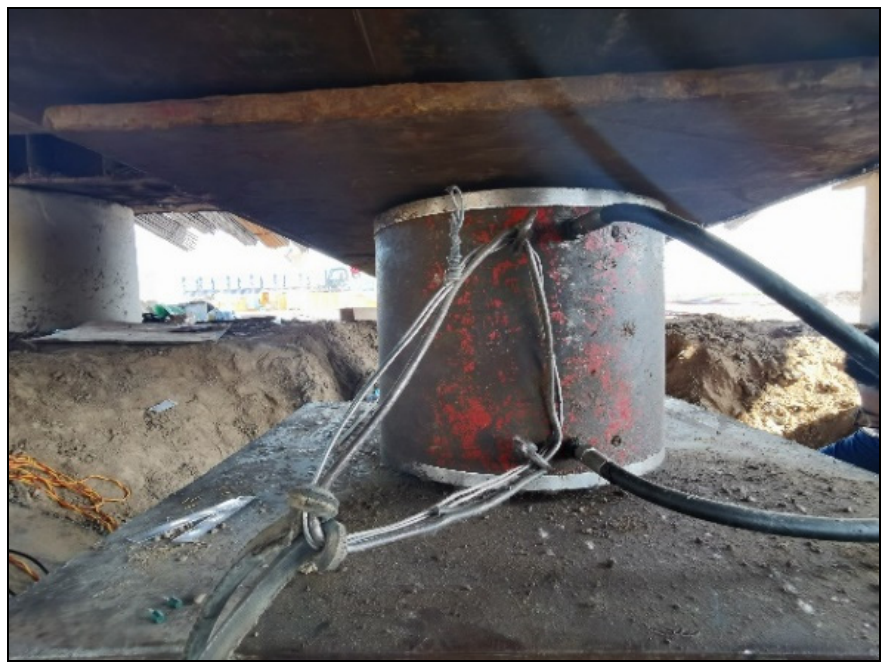

(a)

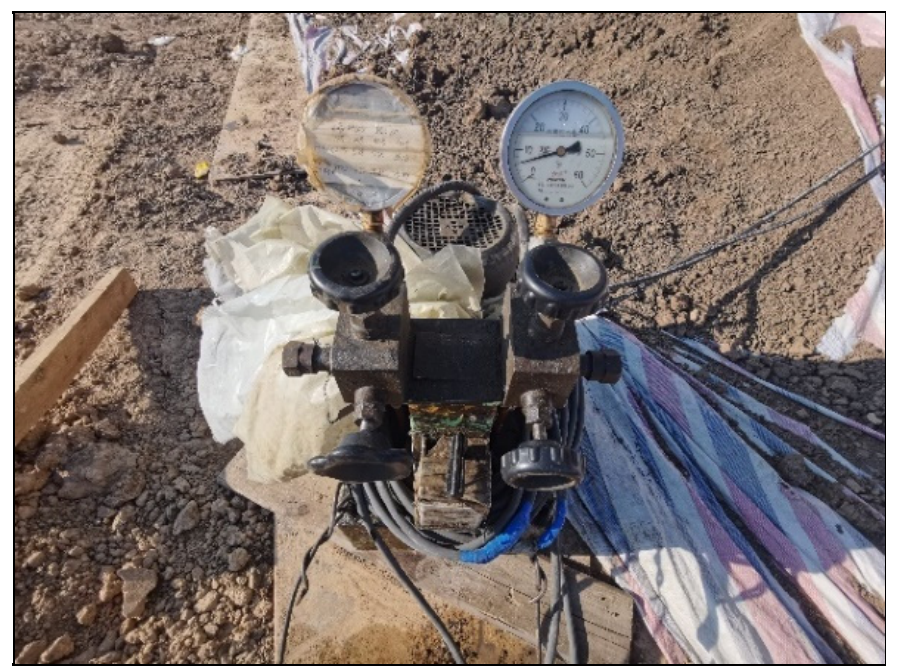

(b)

Figure 4. Loading jack. (a) Hydraulic jack. (b) Pressure gauge.

\subsection{Arrangement of the Displacement and Strain Measurement Points}

\subsubsection{Arrangement of the Displacement Measurement Points}

Four linear variable differential transformers (LVDTs) and four dial indicators were fixed on the reference beam with a magnetic gauge base and symmetrically arranged along the circumference of the pile to measure the displacement. The measurement range of the LVDT was $\pm 20 \mathrm{~mm}$, the measurement error was $0.1 \% \mathrm{FS}$, the resolution was $0.1 \mathrm{~mm}$ and the sensitivity was $20 \mathrm{mV} / \mathrm{mm}$. The measurement range of the dial indicator was $30 \mathrm{~mm}$, and the resolution was $0.01 \mathrm{~mm}$. The displacement measurement section was $0.5 \mathrm{~m}$ from the pile top. Both ends of the reference beam were independently connected to the circular concrete pier by welding without contacting the test pile. The layout of the displacement measurement points and reference beam are shown in Figure 5.

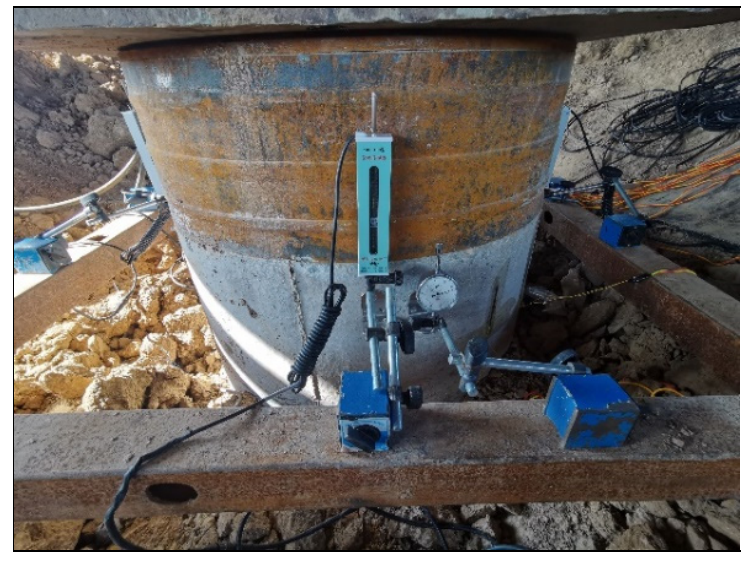

(a)

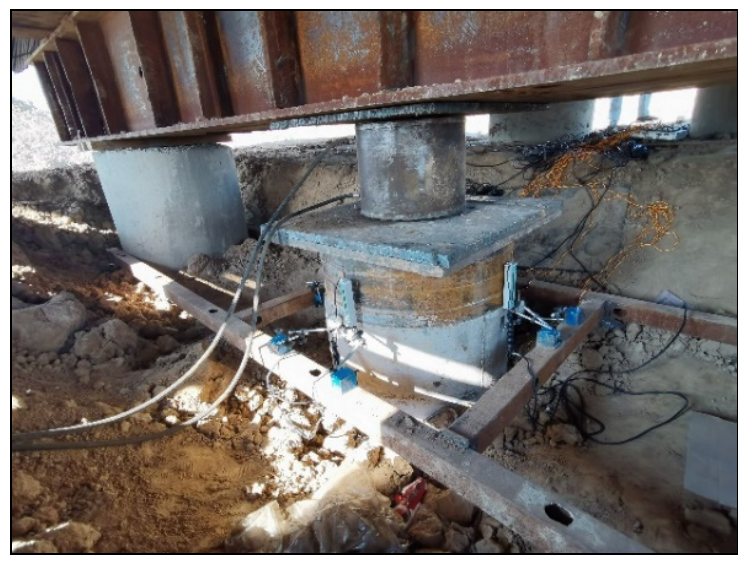

(b)

Figure 5. Arrangement of the displacement measurement points. (a) Displacement meters and dial indicators. (b) Reference beam. 


\subsubsection{Arrangement of the Strain Measurement Points}

The purpose of measurement via embedded resistance strain gauges was to determine the strain of each section to calculate the axial force and shaft resistance of the pile from the strain. In combination with the distribution characteristics of the soil layer, the first section in this test was selected to be $3.6 \mathrm{~m}$ from the pile top, and the other sections were selected every $3.6 \mathrm{~m}$ along the pile length direction. A total of 10 test sections were selected. Four resistance strain gauges were evenly arranged around the circumference of the pile on the inner surface for each section, and the wires were led out to the pile top. Thus, there were 40 resistance strain measurement points for the test pile. The resistance of the strain gauge was $120 \pm 0.5 \Omega$, the sensitivity coefficient was $20 \pm 0.01$ and the temperature range was $-20{ }^{\circ} \mathrm{C}-80{ }^{\circ} \mathrm{C}$. The strain gauge arrangement is shown in Figure 6.

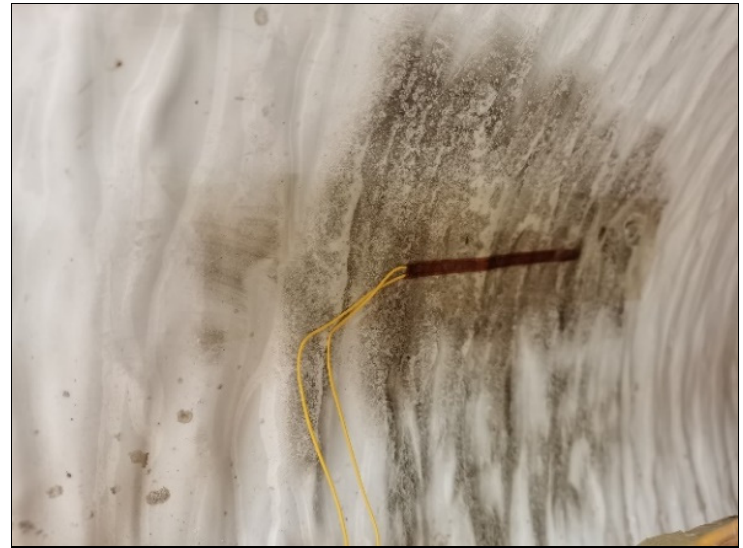

(a)

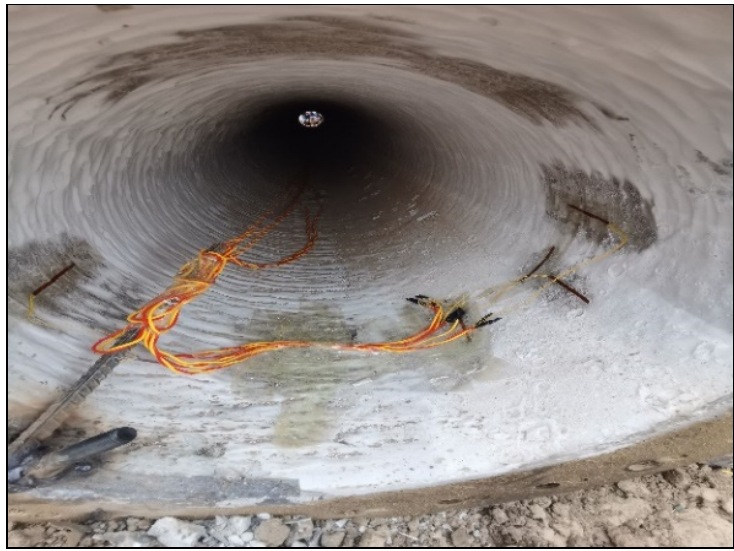

(b)

Figure 6. Arrangement of the strain measurement points. (a) Single strain gauge. (b) Strain gauge connection.

\subsection{Connection Mode of Measurement Points}

The test data acquisition device was a Donghua data acquisition instrument. The wire connection mode was based on the principle of Wheatstone bridges. The displacement measurement points were connected by a Wheatstone half-bridge, and the strain measurement points were connected by a Wheatstone quarter-bridge. DH3815 V2.0 software was used for data reading. The connection modes of the measurement points are shown in Figure 7.

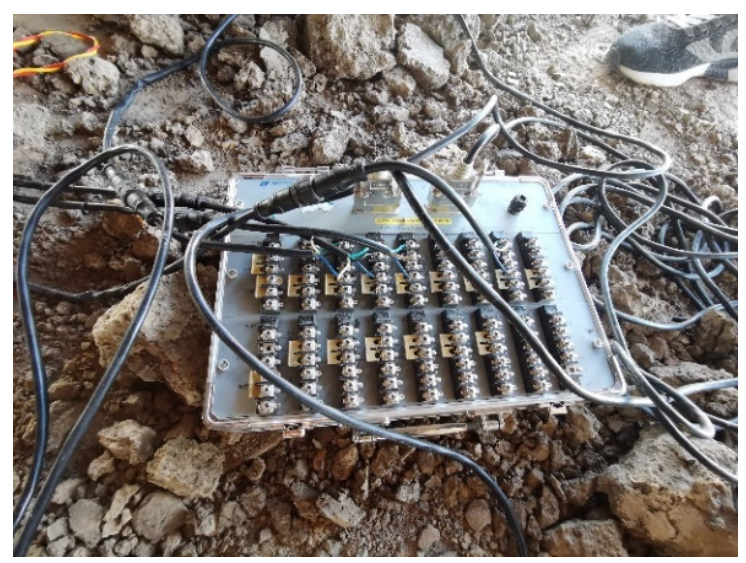

(a)

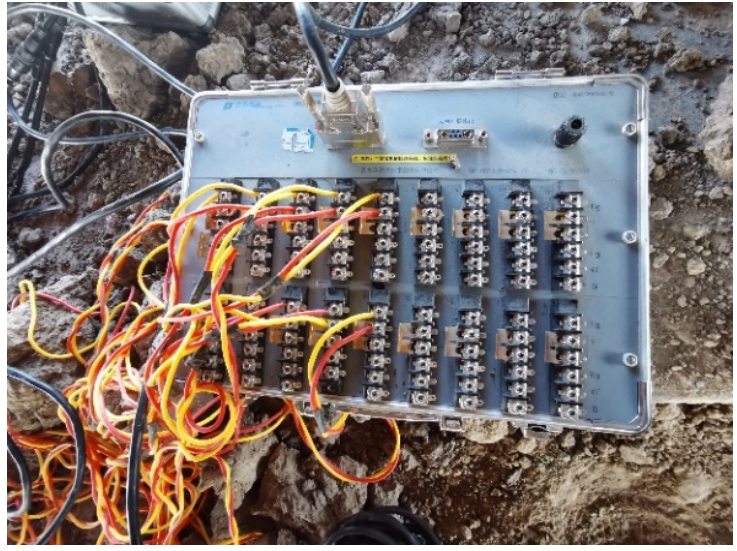

(b)

Figure 7. Connection mode of measurement points. (a) Connection mode of displacement measurement points. (b) Connection mode of strain measurement points. 


\subsection{Test Scheme}

\subsubsection{Loading and Settlement Observation}

This test adopted equal graded loading, and the loading amount of each level was $1 / 10$ of the test load. Under the action of a certain load level, when the corresponding settlement value within $1 \mathrm{~h}$ was less than $0.1 \mathrm{~mm}$, the settlement of this level was deemed stable. Subsequently, the next load level was loaded. The settlement reading time under each load level was $0,5,15,30,45$ and $60 \mathrm{~min}$, and then every $1 \mathrm{~h}$ until the settlement reached the standard of stability. The loads at all grades of the test pile are shown in Table 2.

Table 2. Current stage load and total load of the test pile.

\begin{tabular}{cccccc}
\hline Load Grade & $\begin{array}{c}\text { Current Stage Load } \\
\mathbf{( k N )}\end{array}$ & $\begin{array}{c}\text { Cumulative Load } \\
\mathbf{( k N )}\end{array}$ & Load Grade & $\begin{array}{c}\text { Current Stage Load } \\
\mathbf{( k N )}\end{array}$ & $\begin{array}{c}\text { Cumulative Load } \\
\mathbf{( k N )}\end{array}$ \\
\hline 1 & 700 & 700 & 6 & 700 & 4200 \\
2 & 700 & 1400 & 7 & 700 & 4900 \\
3 & 700 & 2100 & 9 & 700 & 5600 \\
4 & 700 & 2800 & 10 & 700 & 6300 \\
5 & 700 & 3500 & & & 700 \\
\hline
\end{tabular}

\subsubsection{Unloading and Rebound Observation}

Unloading was also carried out in grades, and the unloading amount of each grade was the value of two load grades. After each grade of load was unloaded, three readings were taken, the first two at an interval of $15 \mathrm{~min}$ and the third at an interval of $30 \mathrm{~min}$, before proceeding to the next level of unloading. After complete unloading, readings were taken every $30 \mathrm{~min}$ for at least $3 \mathrm{~h}$.

\subsubsection{Principles of End Loading}

The principles of end loading are as follows [27]:

1. The settlement of the tested pile under a certain load level is greater than five times that of the previous load level, and the total settlement of the pile top is greater than $40 \mathrm{~mm}$.

2. The settlement of the tested pile under a certain load level is greater than twice that of the previous level, and it is not stable after $24 \mathrm{~h}$. The total settlement of the pile top is greater than $40 \mathrm{~mm}$.

3. When the P-s curve slowly changes, the pile can be loaded to the total settlement of the pile top of $60 \sim 80 \mathrm{~mm}$.

4. When the engineering pile is accepted, the load has reached 2.0 times the allowable bearing capacity or the maximum load required by design, and the settlement has reached stability.

\subsubsection{Evaluation Methods of the Vertical UBC of Pipe Piles}

The evaluation methods of the UBC are as follows [27]:

(1) The UBC is determined according to the characteristics of settlement changing with load: for a steeply changing P-s curve, the load value corresponding to the starting point of the steep drop is taken.

(2) The UBC is determined according to the characteristics of settlement changing with time: the load value of the previous grade with prominent downward bending at the tail of the s-lgt curve is taken.

(3) When the settlement of the tested pile under a certain grade of load is greater than twice that of the previous grade and is not stable after $24 \mathrm{~h}$ and the total settlement of the pile top is greater than $40 \mathrm{~mm}$, the load value of the previous grade should be taken.

(4) The slowly changing P-s curve can be determined according to the settlement: the load corresponding to the pile settlement of $40 \mathrm{~mm}$ is taken. 


\subsection{Test Results Analysis}

3.5.1. Analysis of the Load-Settlement Relationship

The settlement of the test pile under various loads and the cumulative settlement are shown in Table 3.

Table 3. Summary of the settlement results.

\begin{tabular}{|c|c|c|c|c|c|}
\hline $\begin{array}{l}\text { Load } \\
(\mathrm{kN})\end{array}$ & $\begin{array}{c}\text { Current Stage } \\
\text { Settlement }(\mathrm{mm})\end{array}$ & $\begin{array}{c}\text { Cumulative } \\
\text { Settlement (mm) }\end{array}$ & $\begin{array}{l}\text { Load } \\
(\mathrm{kN})\end{array}$ & $\begin{array}{c}\text { Current Stage } \\
\text { Settlement }(\mathrm{mm})\end{array}$ & $\begin{array}{c}\text { Cumulative } \\
\text { Settlement }(\mathrm{mm})\end{array}$ \\
\hline 0 & 0 & 0 & 5600 & 2.33 & 13.16 \\
\hline 700 & 1.21 & 1.21 & 6300 & 2.62 & 15.77 \\
\hline 1400 & 1.26 & 2.47 & 7000 & 2.93 & 18.71 \\
\hline 2100 & 1.31 & 3.78 & 5600 & -0.76 & 17.95 \\
\hline 2800 & 1.47 & 5.25 & 4200 & -0.84 & 17.11 \\
\hline 3500 & 1.65 & 6.90 & 2800 & -0.85 & 16.26 \\
\hline 4200 & 1.85 & 8.75 & 1400 & -0.95 & 15.31 \\
\hline 4900 & 2.08 & 10.83 & 0 & -1.20 & 14.11 \\
\hline
\end{tabular}

The deformation is positive in the downward direction. The data in the table are the readings of the displacement meter when loading or unloading for $2 \mathrm{~h}$, but the last item corresponds to unloading for $3 \mathrm{~h}$.

According to the corresponding relationship between the load and settlement under various loads, the P-s curve and s-lgt curve are drawn, as shown in Figure 8.

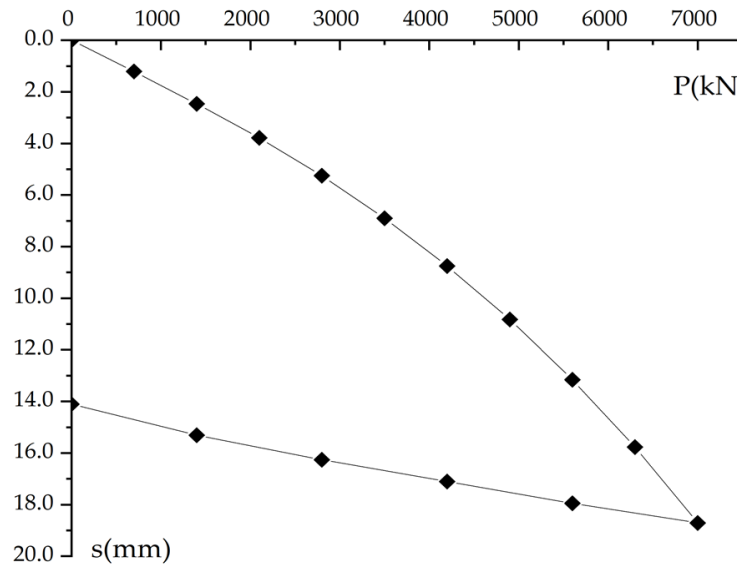

(a)

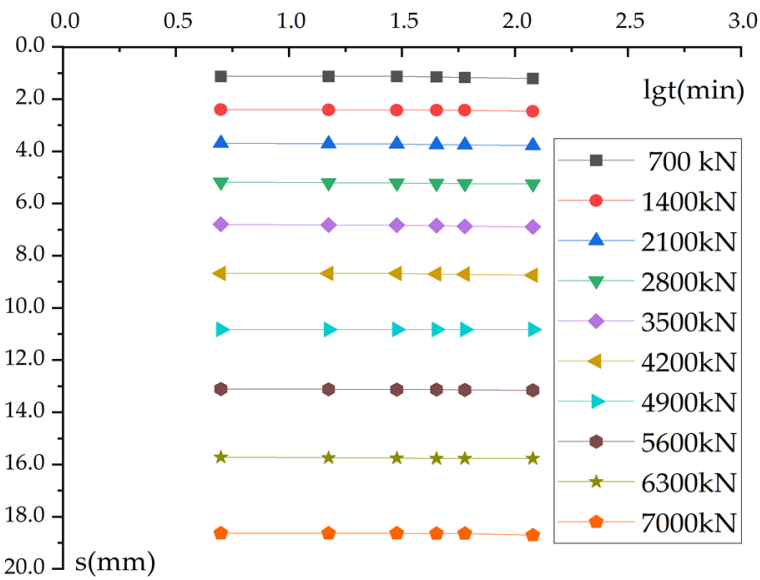

(b)

Figure 8. Load-settlement relationship. (a) P-s curve. (b) s-lgt curve.

As shown in Table 3 and Figure 8, the settlement of the pipe pile increases with increasing load. When the load does not exceed $2100 \mathrm{kN}$, the settlement of the pipe pile exhibits a linear growth relationship with the load, indicating that the pile is in the elastic stage. When the value is greater than $2100 \mathrm{kN}$, the growth rate increases continuously, showing that the pipe pile enters the plastic working state. When the load grade is the maximum, the settlement is $18.71 \mathrm{~mm}$, and there is no sharp increase in the slopes of the P-s curve and s-lgt curve, demonstrating that the soil around the pile does not yield under maximum loading and that the pile has a good bearing capacity. The final rebound is $4.6 \mathrm{~mm}$, and the rebound rate is $75.4 \%$, indicating that the settlement of this test is mainly due to plastic deformation of the soil around the pile.

\subsubsection{Analysis of the Axial Force Transfer of a Pile}

According to the strain data of each section of the pile shaft measured by the embedded concrete strain gauge, the axial force corresponding to each load level can be calculated. The calculation formula is [26]:

$$
P_{i}=\eta A_{P} \sigma_{i}
$$


In the above formula, $P_{i}$ is the axial force of the pile under a grade $i$ load, $\eta$ is a correction factor and is taken as 1.0, $A_{P}$ is the sectional area of the pile, $\sigma_{i}$ is the average compressive stress of each section; its value is equal to the sectional strain multiplied by the corresponding Young's modulus.

The axial force distribution is obtained by arranging the readings of the strain gauges embedded in the pile at different depths, as shown in Figure 9.

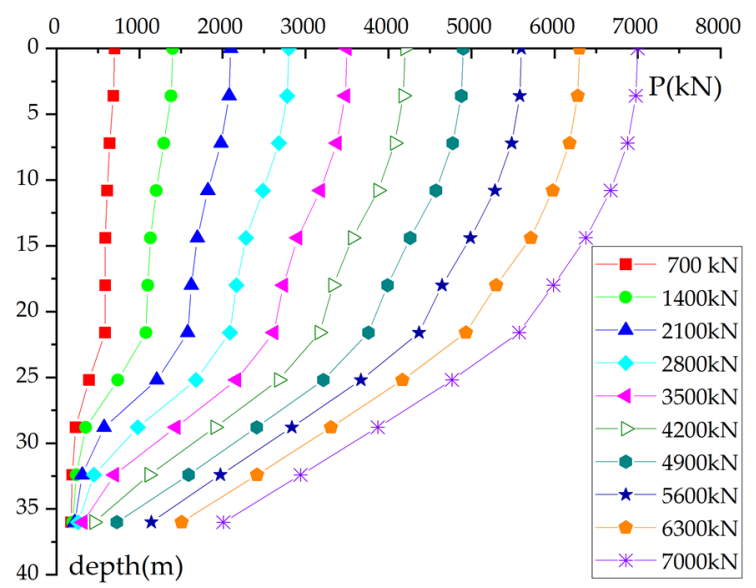

Figure 9. Axial force distribution of the pile along its depth.

According to Figure 9, the axial force of the pile at the same depth increases gradually with increasing load grade. Under the same load grade, the axial force (AF) is negatively correlated with increasing depth. The steepness of the curve indicates the change rate of the AF and the exertion degree of the pile shaft resistance (PSR). The steeper the curve is, the smaller the change in AF and the degree of PSR. At the beginning of loading, the curve is generally steep, indicating that the PSR is small. As the load increases, the curve gradually flattens, indicating a greater degree of PSR.

For the curve under a certain load level, the steepness of the curve in the depth range of more than $22 \mathrm{~m}$ is much greater than that in the depth range of less than $22 \mathrm{~m}$, indicating that the PSR below $22 \mathrm{~m}$ is greater. The reasons for this trend are summarized as follows: the soil layer below $22 \mathrm{~m}$ is mudstone, with high cohesion and a large internal friction angle, and it strongly interacts with the pile, resulting in PSR.

\subsubsection{Analysis of the PSR Distribution}

The PSR can be calculated by using the pile shaft AF of each section. The calculation formula is [26]:

$$
\tau_{i}=\frac{P_{i-1}-P_{i}}{U_{P} l_{i}}
$$

In the above formula, $\tau_{i}$ is the average PSR of section $i, P_{i}$ and $P_{i-1}$ are the AFs corresponding to section $i$ and section $i-1$, respectively, $U_{P}$ is the average circumference of a pile section, and $l_{i}$ is the length of the pile between section $i$ and section $i-1$.

The PSR calculated based on the AF of each section is shown in Figure 10.

Figure 10 shows that for a soil layer at the same depth, the PSR is small at the beginning of loading, and with increasing load grade, the PSR gradually improves. Under the same load grade, the shaft resistance below $22 \mathrm{~m}$ is the largest. For the soil above $22 \mathrm{~m}$, the pile-soil friction in the 7-12 $\mathrm{m}$ range is greater when loading at the first grade. With increasing load grade, the soil layer in the $12-22 \mathrm{~m}$ range is mobilized, and the maximum PSR area gradually moves downward. For the soil layer below $22 \mathrm{~m}$, the PSR also follows this development trend. The PSR in each soil layer is gradually exerted along with the pile with increasing load. 


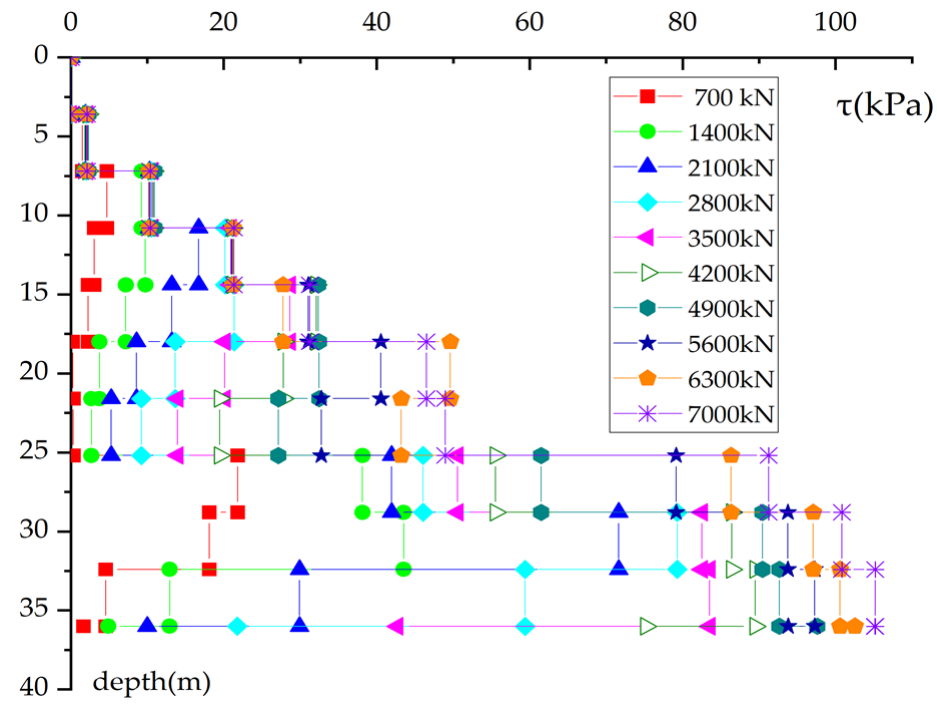

Figure 10. PSR distribution.

\subsubsection{Analysis of PTR}

In Figure 7, the AF of the pile at $36 \mathrm{~m}$ under each load grade can represent the pile tip resistance (PTR). The variation curve of the PTR and its percentage of the load applied with load grade is shown in Figure 11.

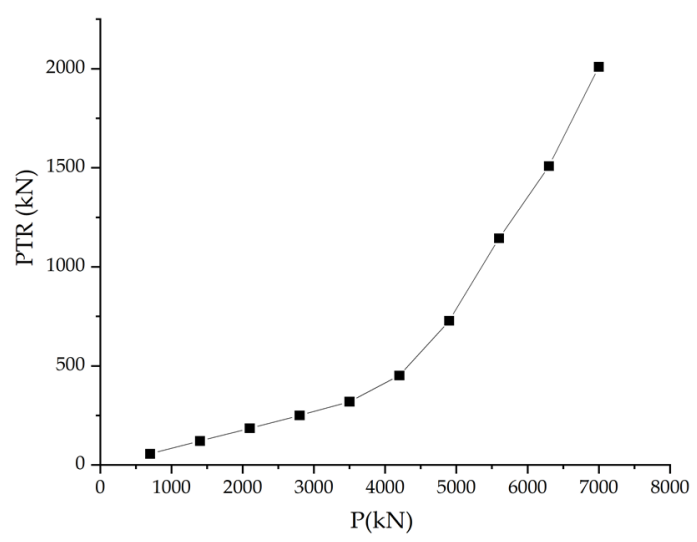

(a)

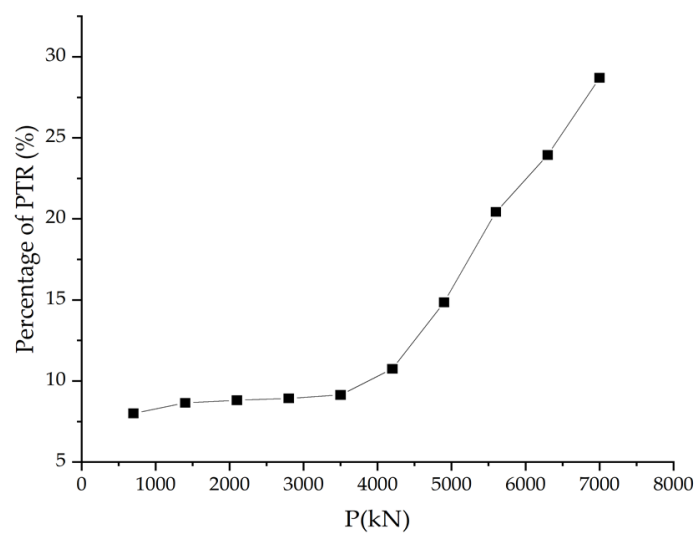

(b)

Figure 11. Variation in PTR and its percentage of the load applied with load grade. (a) Value of PTR. (b) Percentage of PTR to loading.

Figure 11 show that with increasing load grade, the PTR gradually increases, the percentage of PTR also has the same change trend, and the relationship between the two increases exponentially. At the beginning of loading, the pile bearing capacity is mainly provided by the PSR, and the PTR is $56.04 \mathrm{kN}$, accounting for only $8.01 \%$. At the maximum load grade tested, the PTR is $2009.14 \mathrm{kN}$, accounting for $27.70 \%$, which is a contribution that cannot be ignored.

\section{Numerical Analysis}

In this section, ABAQUS V6.14 is used to establish the pile-soil interaction model. The temperature, Young's modulus of the soil at the pile tip, pile-soil friction coefficient, pile length and the ratio of the outer diameter to the inner diameter are selected as control factors to explore their impact on the UBC of pipe piles to provide a reference for followup studies. 


\subsection{Finite Element Model}

\subsubsection{Model Description}

Since the pile-soil structure is an axisymmetric structure and the research object is the vertical bearing capacity of the pile, to reduce the number of calculations, a 1/2-pile-soil model is established for research. The finite element model applied to the analysis adopts hexahedral elements called C3D8. The Young modulus of concrete is $38 \mathrm{GPa}$, the Poisson ratio is 0.3 , and the density is $2500 \mathrm{~kg} / \mathrm{m}^{3}$. The soil model is $72 \mathrm{~m} \times 36 \mathrm{~m} \times 18 \mathrm{~m}$, the MohrCoulomb yield criterion is adopted, and the parameters, cohesion and internal friction angle used are shown in Table 1. The pile-soil interaction is simulated by face-to-face contact, its tangential behavior adopts a penalty function, the friction coefficient is 0.3 , and the normal contact type is hard contact. To simulate the state of the pipe pile and soil, the boundary conditions of the model are set as follows: the bottom layer of the soil constrains the degrees of freedom in all directions, the sides of the soil constrain the degrees of freedom in the normal direction, and the other degrees of freedom are free. The pipe pile constrains the lateral freedom only, and the other degrees are placed freely. The model is shown in Figure 12.

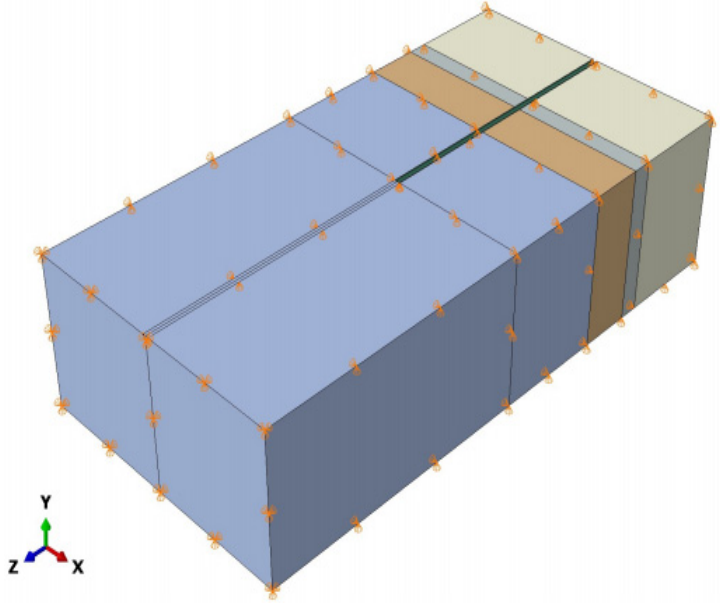

(a)

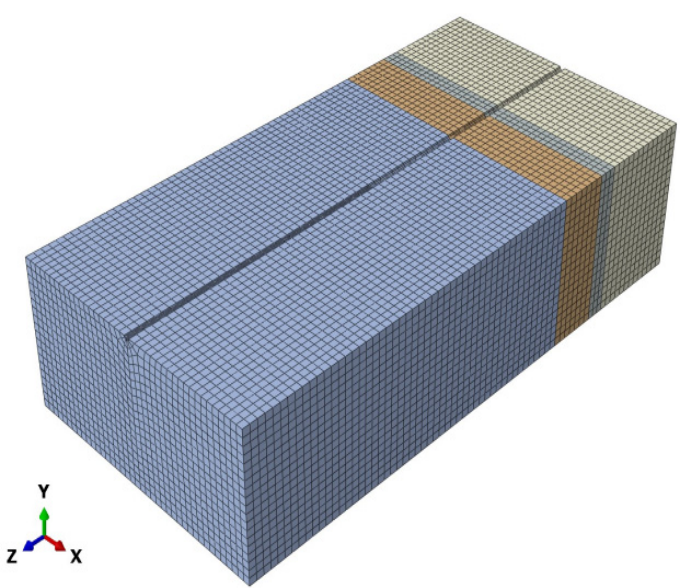

(b)

Figure 12. Finite element model. (a) Boundary conditions. (b) Meshing.

\subsubsection{Model Verification}

To verify the accuracy of the model, the following steps are taken: the model is loaded step by step according to the grades in Table 2, and the resulting P-s curve is drawn and compared with the test results. A comparison of the results is shown in Figure 13.

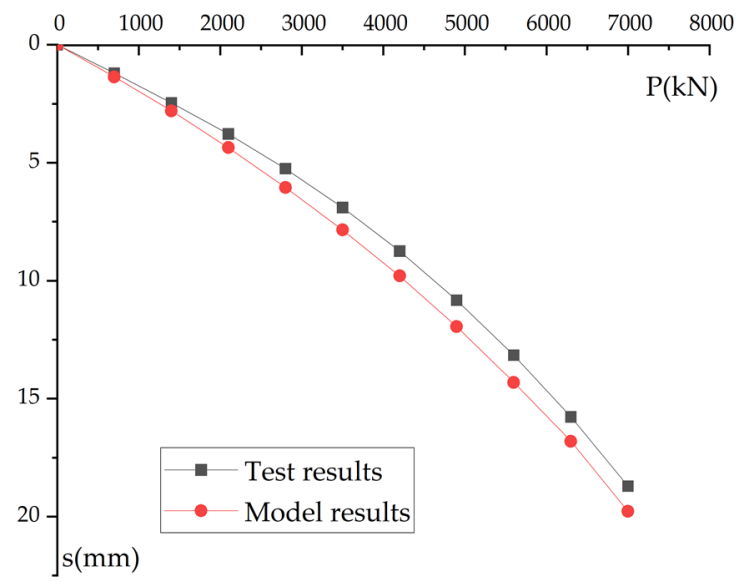

Figure 13. Comparison between model results and test results. 
As shown in Figure 13, the change trends of the test and model P-s curves are basically the same. The model settlement is $19.78 \mathrm{~mm}$, the test settlement is $18.71 \mathrm{~mm}$ and the relative error between them is $5.4 \%$. Therefore, this model can accurately reflect the working situation of pipe piles.

\subsection{Analysis of Key Factors}

\subsubsection{Influence of Temperature}

The influence of temperature on the UBC of pipe piles cannot be ignored [28,29]. Based on the finite element model described in Section 4.1, a thermal load is applied on the pile surface and soil surface to transfer the temperature along the depth of the soil to study the variation in the pipe pile bearing capacity under the action of temperature.

In the ABAQUS model, the initial temperature of the soil is $0{ }^{\circ} \mathrm{C}$, and the temperature of the lower surface of the soil is $0^{\circ} \mathrm{C}$; the temperature of the upper surface of the soil is changed to $0{ }^{\circ} \mathrm{C},-1{ }^{\circ} \mathrm{C},-2{ }^{\circ} \mathrm{C},-3{ }^{\circ} \mathrm{C},-4{ }^{\circ} \mathrm{C}$ and $-5^{\circ} \mathrm{C}$. The thermal parameters of the concrete and soil involved in this simulation are shown in Table 4.

Table 4. Thermal parameters of concrete and soil.

\begin{tabular}{|c|c|c|c|}
\hline Name & $\begin{array}{l}\text { Volumetric Heat Capacity } \\
\left(\mathrm{W} /\left(\mathrm{m} \cdot{ }^{\circ} \mathrm{C}\right)\right)\end{array}$ & $\begin{array}{l}\text { Thermal Conductivity } \\
\qquad\left(\mathrm{kJ} /\left(\mathrm{m}^{3} \cdot{ }^{\circ} \mathrm{C}\right)\right)\end{array}$ & $\begin{array}{l}\text { Coefficient of Expansion } \\
\left(1 /{ }^{\circ} \mathrm{C}\right)\end{array}$ \\
\hline Concrete & 1.28 & 2425 & $1 \times 10^{-5}$ \\
\hline Silty clay & 0.26 & 1254 & $1 \times 10^{-5}$ \\
\hline Coarse grit & 0.98 & 1400 & $1 \times 10^{-5}$ \\
\hline Weathered sandstone & 1.09 & 1560 & $1 \times 10^{-5}$ \\
\hline Mudstone & 4.5 & 3560 & $1 \times 10^{-5}$ \\
\hline
\end{tabular}

The analysis is performed as follows: the calculation results of the model pile top displacement are extracted and the UBC according to the evaluation method is listed in Section 3.4.4. The results are shown in Figure 14 (the initial value is $10,400 \mathrm{kN}$ ).

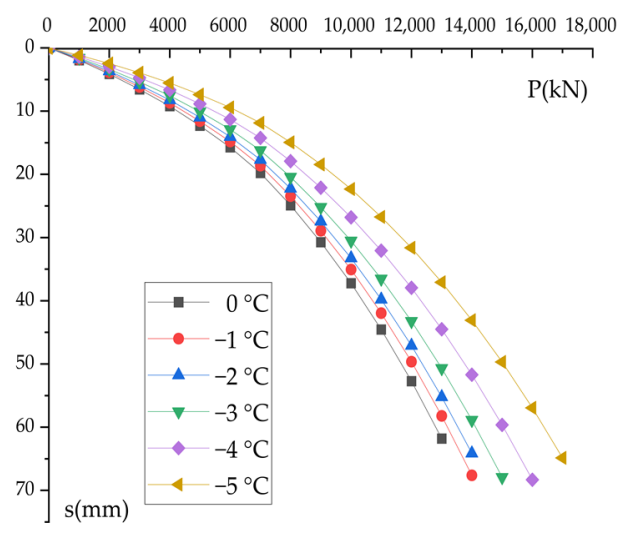

(a)

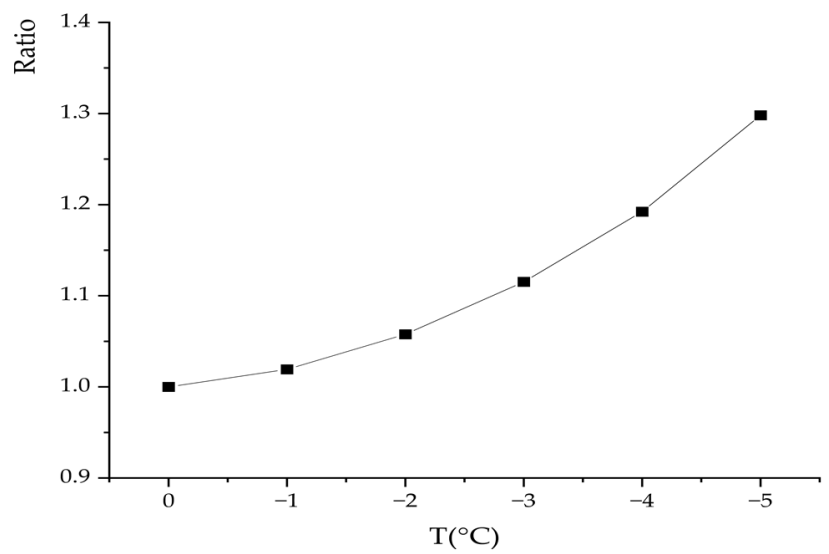

(b)

Figure 14. Variation in the UBC of pipe pile with temperature. (a) P-s curve. (b) Ratio of the current value to the initial value.

According to Figure 14a, the low-temperature environment has an impact on the UBC of pipe piles that cannot be ignored. Under the same load, when the temperature is lower than $0{ }^{\circ} \mathrm{C}$, the settlement of the pile is less than that under a normal-temperature environment, and the settlement gradually decreases with decreasing temperature. The reasons for this trend are summarized as follows: in the low-temperature environment, the soil freezes, and the freezing stress between the pile and soil produces a certain resistance, which reduces the settlement of the pile. When the ground temperature is $-1{ }^{\circ} \mathrm{C}$, the temperature is transmitted downward, and the soil layer near the ground begins to freeze. 
With decreasing temperature, the freezing depth deepens. When the ground temperature is $-5^{\circ} \mathrm{C}$, the depth of frozen soil around the pile reaches the maximum obtained in this study, and the freezing strength between the pile and soil is also the maximum. Thus, the load resistance capacity is the maximum and the settlement of the pile is the minimum.

In Figure 14b, the UBC of a pipe pile gradually increases with decreasing temperature: when the temperature is $-1{ }^{\circ} \mathrm{C}$, the ratio is 1.02 ; when the temperature is $-5^{\circ} \mathrm{C}$, the ratio is 1.30. In addition, the growth trend gradually increases. With the decrease in surface temperature, the difference between the surface and the deeper soil increases, the transfer rate of temperature in the soil accelerates and the soil within a larger depth range freezes to enhance the UBC of the pile.

\subsubsection{Influence of the Young Modulus of the Soil at the Pile Tip}

The mechanical characteristics of the soil at the pile tip, as the bearing stratum of pile foundations, play an important role in the UBC of pile foundations. Especially for end-bearing piles, the UBC is mainly provided by the soil at the pile tip [30]. Based on the finite element model in Section 4.1, the Young modulus of the soil at the pile tip is changed to explore the variation in the UBC of the pile according to the P-s curves obtained under different conditions. The values of the Young modulus of the soil at the pile tip considered are shown in Table 5.

Table 5. Young's moduli of the soil at the pile tip.

\begin{tabular}{cccccc}
\hline Condition & Condition 1 & Condition 2 & Condition 3 & Condition 4 & Condition 5 \\
\hline Young's modulus $(\mathrm{MPa})$ & 100 & 200 & 400 & 800 & 2000 \\
\hline
\end{tabular}

The calculation results of the model pile top displacement are shown in the broken line diagram in Figure 15 (the initial value is $10,400 \mathrm{kN}$ ).

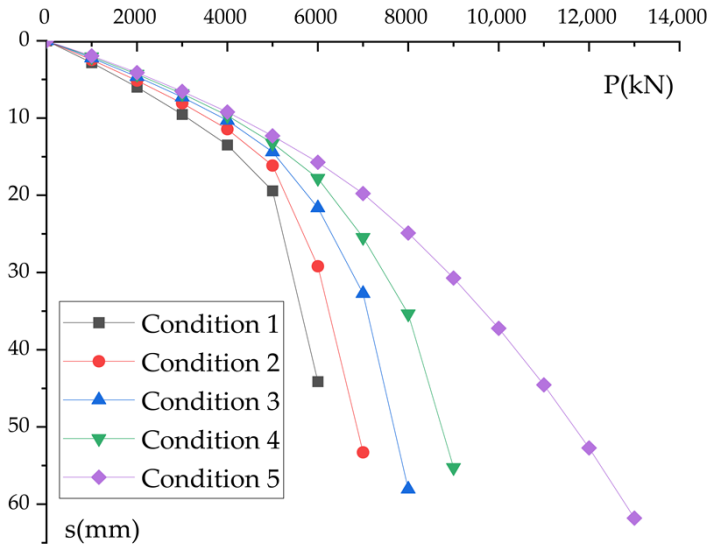

(a)

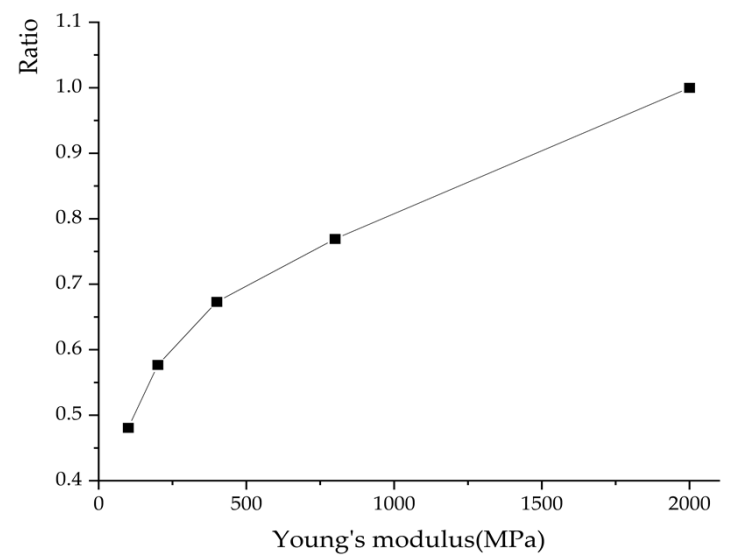

(b)

Figure 15. Variation in the UBC of a pipe pile with the Young modulus of the soil at the pile tip. (a) P-s curve. (b) Ratio of the current value to the initial value.

As shown in Figure 15a, the effect of the Young modulus of the soil at the pile tip cannot be underestimated. The larger the Young modulus is, the smaller the settlement of the pipe pile foundation under the same load level. Conditions 1-4 show steep changes, and condition 5 shows slow changes. Due to the fact that the Young moduli of conditions 1-4 are very small, the excessive load causes shear failure at the pile-soil contact interface and a rapid increase in settlement. When the Young modulus of the soil at the pile tip is large, the soil can provide a strong PTR for the pile foundation, so there is no abrupt change. 
According to Figure 15b, the UBC gradually improves with increasing the Young modulus. When the Young modulus is $100 \mathrm{MPa}$, the ratio is 0.48 , and when the Young modulus is $2000 \mathrm{MPa}$, the ratio is 1.00 . Although the Young modulus increases by 20 times, the bearing capacity only doubles. The growth rate gradually decreases.

\subsubsection{Influence Analysis of the Pile-Soil Friction Coefficient}

Based on the finite element model in Section 4.1, the pile-soil friction coefficient is changed to explore the variation in the UBC of the pile according to the P-s curve under different conditions. The values of the pile-soil friction coefficient considered are shown in Table 6.

Table 6. Pile-soil friction coefficients.

\begin{tabular}{ccccccc}
\hline Condition & Condition 1 & Condition 2 & Condition 3 & Condition 4 & Condition 5 \\
\hline Friction coefficient & 0.3 & 0.4 & 0.5 & 0.6 & 0.7 \\
\hline
\end{tabular}

The calculation results of the model pile top displacement are shown in the broken line diagram in Figure 16 (the initial value is $10,400 \mathrm{kN}$ ).

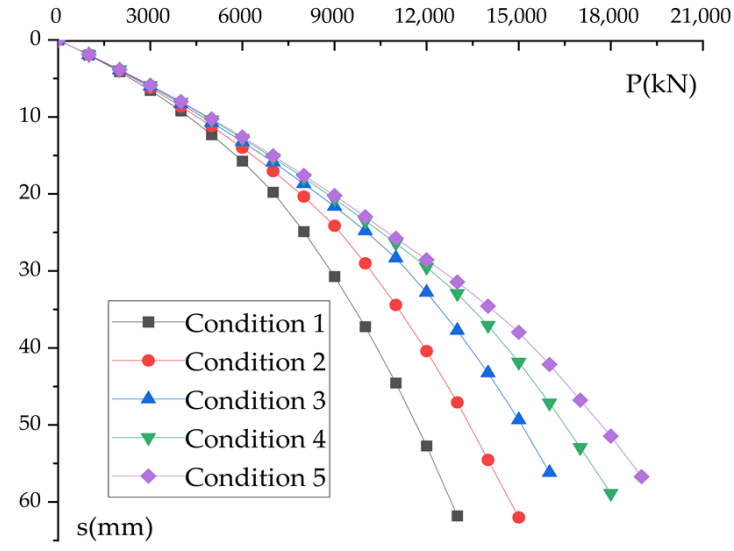

(a)

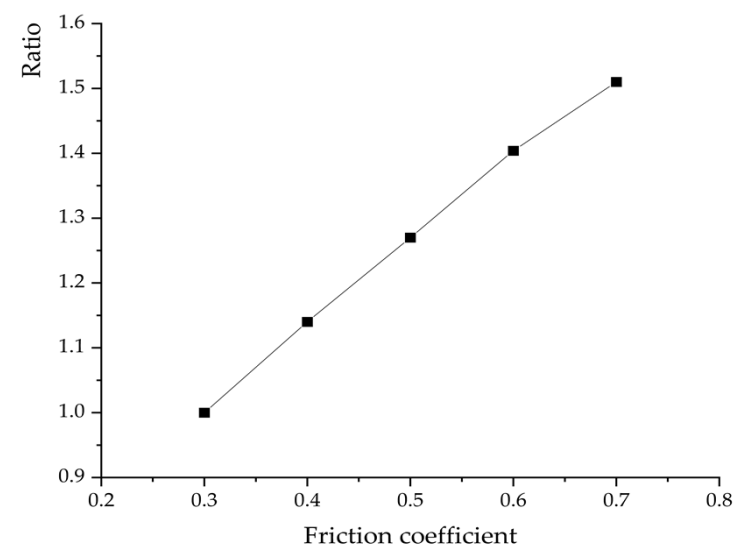

(b)

Figure 16. Variation in the UBC of a pipe pile with the pile-soil friction coefficient. (a) P-s curve. (b) Ratio of the current value to the initial value.

In Figure 16a, the P-s curves of different friction coefficients have the same change trend, all showing a slow change. Under the same grade load, the larger the friction coefficient is, the smaller the pile settlement. As the friction coefficient increases, the PSR of the same section also increases, which strongly resists pipe pile settlement.

According to Figure 16b, the larger the friction coefficient is, the greater the UBC. When the friction coefficient increases by 0.1 , the ratio increases by approximately 0.13 . When the friction coefficient is 0.7 , the ratio is 1.51 . The trend is approximately linear. In practical engineering applications, appropriate measures should be adopted to increase the friction coefficient.

\subsubsection{Influence Analysis of Pile Length}

When the bearing capacity of a pile is not sufficient to maintain the stability of the superstructure it is supporting, increasing the pile length is an effective method of correcting this issue [30]. Based on the finite element model in Section 4.1, the pile length is changed to explore the variation in the UBC of the pile according to the P-s curve under different working conditions. The values of the pile length considered are shown in Table 7. 
Table 7. Pile lengths.

\begin{tabular}{cccccc}
\hline Condition & Condition $\mathbf{1}$ & Condition 2 & Condition 3 & Condition 4 & Condition 5 \\
\hline Pile length & 12 & 18 & 24 & 30 & 36 \\
\hline
\end{tabular}

The calculation results of the model pile top displacement are shown in the broken line diagram in Figure 17 (the initial value is 10,400 kN).

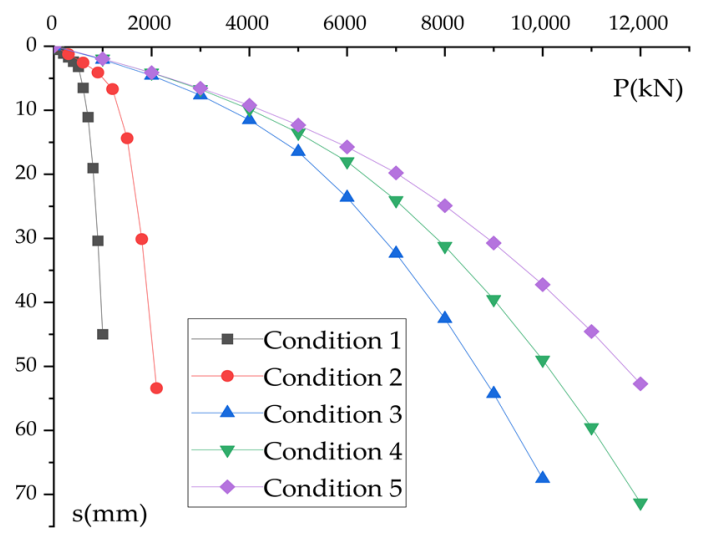

(a)

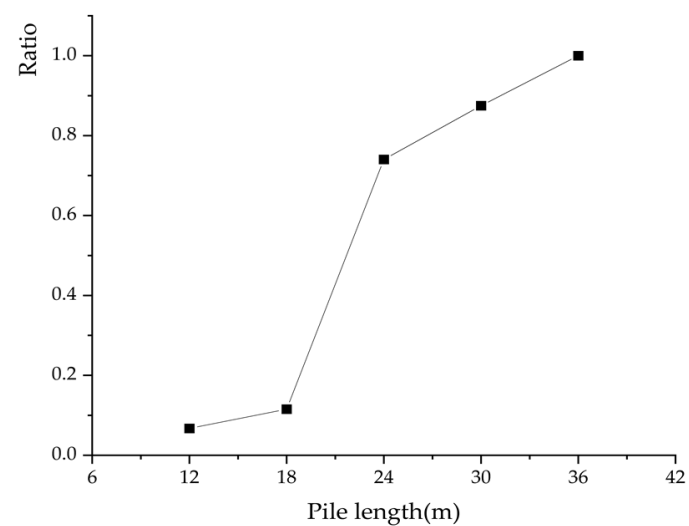

(b)

Figure 17. Variation in the UBC of a pipe pile with pile length. (a) P-s curve. (b) Ratio of the current value to the initial value.

According to Figure 17a, under the same load grade, the settlement decreases with increasing pile length. The P-s curves can be categorized into two types: pile lengths of $12 \mathrm{~m}$ and $18 \mathrm{~m}$ correspond to steep change; pile lengths of $24 \mathrm{~m}, 30 \mathrm{~m}$ and $36 \mathrm{~m}$ correspond to slow change. When the pile length is $12 \mathrm{~m}$, the soil layer where the pile is located is silty clay, which is a relatively weak soil layer, and only the PSR provides the capacity for the pile. When the load reaches a certain value, the soil around the pile yields, the pile-soil contact interface undergoes shear sliding, and the settlement increases rapidly. This also occurs with a pile length of $18 \mathrm{~m}$. At $24 \mathrm{~m}$, the pipe pile is supported by mudstone, which provides a large PTR for the pile and hinders its settlement. Therefore, the corresponding settlement curve does not change sharply. As the pile length increases, an increasing length of the pile is embedded in the mudstone, resulting in friction between the mudstone and the pipe pile, which also hinders the settlement.

According to Figure $17 \mathrm{~b}$, an increase in pile length can remarkably increase the UBC, especially when the pile length increases from $18 \mathrm{~m}$ to $24 \mathrm{~m}$. The ratio increases from 0.12 to 0.74 , almost five-fold. The reason is that when the pile is short and supported by the weak soil layer, increasing the pile length essentially increases the friction area and improves the PSR. As the length of the pipe pile increases, when it passes through the weak soil layer and into the hard soil layer or rock stratum, in addition to the friction resistance of the upper soil layer, PTR arises, which greatly improves the UBC of the pile.

\subsubsection{Influence Analysis of the Ratio of the Pile's Outer Diameter to Inner Diameter}

Increasing the pile diameter is also a way to improve its UBC [31]. Based on the finite element model in Section 4.1, the ratio of the outer diameter to the inner diameter is changed to explore the variation in the UBC of the pile according to the P-s curve under different working conditions. The values of this ratio considered are shown in Table 8.

Table 8. Ratios of the outer diameter to the inner diameter.

\begin{tabular}{cccccc}
\hline Condition & Condition $\mathbf{1}$ & Condition 2 & Condition 3 & Condition 4 & Condition 5 \\
\hline Ratio & 1.5 & 1.6 & 1.7 & 1.8 & 1.9 \\
\hline
\end{tabular}


The calculation results of the model pile top displacement are shown in the broken line diagram in Figure 18 (the initial value is 10,400 kN).

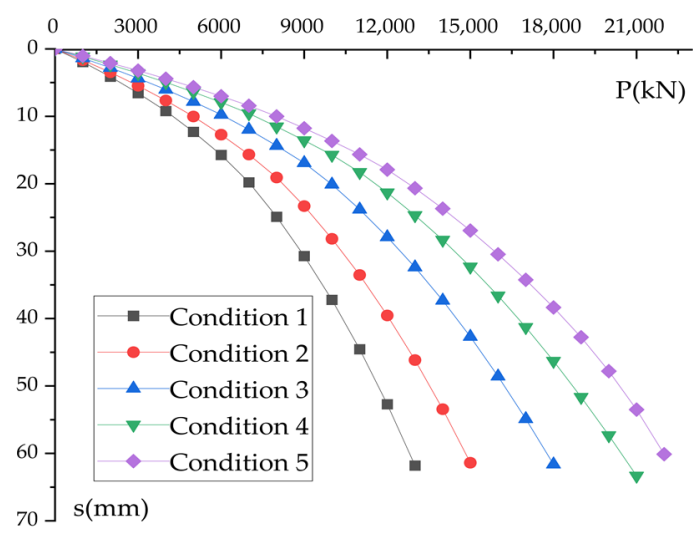

(a)

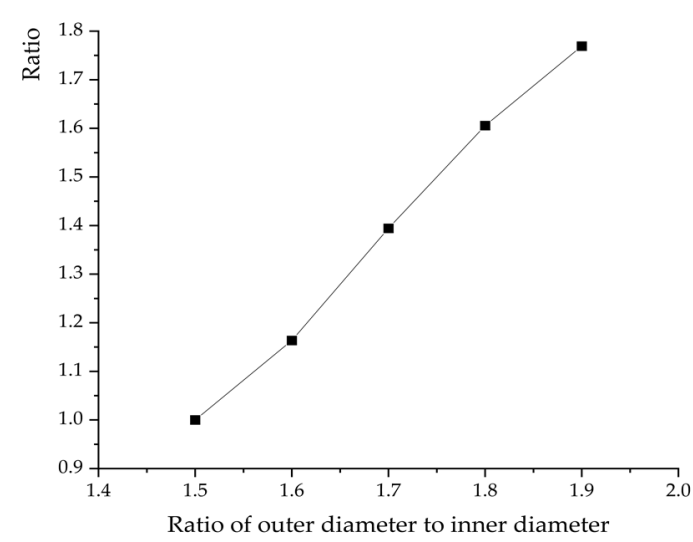

(b)

Figure 18. Variation in the UBC of the pipe pile with the ratio of the outer diameter to the inner diameter. (a) P-s curve. (b) Ratio of the current value to the initial value.

As shown in Figure 18a, the P-s curves of the pile under the five conditions show a slow change. Under the same grade load, as the outer diameter increases, the pile settlement gradually decreases because with the increase in the outer diameter, the pile side area increases, the pile-soil contact area increases, and the PSR significantly increases, which hinders settlement.

According to Figure $18 \mathrm{~b}$, the UBC gradually increases with an increasing diameter ratio. When the ratio increases from 1.5 to 1.9 , the ratio of UBC increases from 1.16 to 1.77. The effect of increasing the pile diameter on the UBC is unambiguous.

\section{Conclusions}

In this paper, first, the load transfer of pipe piles was analyzed through an SLT. Then, pile-soil interaction models were established, and different control parameters are selected to determine the influence of each parameter on the UBC of the pile in multilayer soil. The results are as follows:

(1) In this test, the maximum settlement of the pipe pile is $18.71 \mathrm{~mm}$, the corresponding load is $7000 \mathrm{kN}$, the final rebound after unloading is $4.6 \mathrm{~mm}$, and the rebound rate is $75.4 \%$. The soil layer below $22 \mathrm{~m}$ results in the largest pile-soil friction, a maximum of $105 \mathrm{kPa}$, which plays the most important role in the UBC of pipe piles. The PTR and its percentage in terms of the load applied increase exponentially with increasing load grade. The maximum PTR and its percentage are $2009.14 \mathrm{kN}$ and $27.7 \%$, respectively, and the effect of the PTR should not be neglected.

(2) A low-temperature environment can produce freezing stress at pile-soil interfaces. The lower the temperature is, the stronger the freezing stress and the greater the UBC of the pile. The UBC of a pipe pile gradually increases with decreasing temperature, and the growth trend gradually increases.

(3) The smaller the Young modulus of the pile tip soil is, the smaller the UBC of the pipe pile. When the Young modulus is $100 \mathrm{MPa}$, the ratio is 0.48 , and when the Young modulus is $2000 \mathrm{MPa}$, the ratio is 1.00 . Thus, when the Young modulus increases by 20 times, the bearing capacity only doubles. The growth rate gradually decreases.

(4) The UBC of the pipe pile is linearly related to the friction coefficient. When the friction coefficient increases by 0.1 , the ratio increases by approximately 0.13 . The largest ratio is 1.51 , and the corresponding friction coefficient is 0.7 . 
(5) When the pile length increases from $18 \mathrm{~m}$ to $24 \mathrm{~m}$, the ratio increases from 0.12 to 0.74 , almost fivefold. This is because increasing the pile length changes the bearing layer of the pipe pile and produces PTR.

(6) When the ratio of the outer diameter to the inner diameter increases from 1.5 to 1.9, the ratio of the UBC increases from 1.16 to 1.77 , showing approximately linear growth.

Author Contributions: Conceptualization, X.L., H.X. and Q.G.; methodology, X.L., Q.G. and Z.S.; software, J.Z. and H.X.; validation, X.L., H.X. and Z.S.; formal analysis, X.L. and J.Z.; investigation, H.X. and J.Z.; resources, X.L. and H.X.; data curation, J.Z. and Q.G.; writing-original draft preparation, X.L. and J.Z.; writing-review and editing, Z.S. and Q.G.; supervision, Z.S. and Q.G.; project administration, X.L. and H.X.; funding acquisition, Q.G. All authors have read and agreed to the published version of the manuscript.

Funding: This study is supported by the Key Research and Development Program of Shandong Province of China (Grant No: 2019JZZY010427).

Institutional Review Board Statement: Not applicable.

Informed Consent Statement: Not applicable.

Data Availability Statement: Not applicable.

Conflicts of Interest: The authors declare that they have no known competing financial interest or personal relationships that could have appeared to influence the work reported in this paper.

\section{References}

1. Ahn, S.; Park, G.; Yoon, H.; Han, J.H.; Jun, J.W. Evaluation of soil-structure interaction in structure models via shaking table test. Sustainability 2021, 13, 4995. [CrossRef]

2. Gan, J.S.; Li, P.Z.; Liu, Q. Study on Dynamic structure-soil-structure interaction of three adjacent tall buildings subjected to seismic loading. Sustainability 2020, 12, 336. [CrossRef]

3. Zhao, M.H.; Mu, B.G. Review on China's bridge engineering research. China J. Highw. Transp. 2014, 5, 48-49.

4. Wang, Y.H.; Sang, S.K.; Zhang, M.Y.; Bai, X.Y.; Su, L. Investigation on in-situ test of penetration characteristics of open and closed PHC pipe piles. Soils Found. 2021, 61, 960-973. [CrossRef]

5. Guo, Y.; Cui, W. Experimental study on application of PHC piles in paleo-clay area. Chin. J. Geotech. Eng. 2011, 33, 108-115.

6. Wang, Z.P. Case Analysis of Solving Integral Drifting Problem of PHC Pipe Pile Foundation. Struct. Eng. 2005, 2, 60-64.

7. Ren, F. The Problem of Static Prestressed Pipe Pile in the Engineering. Urban. Archit. 2012, 17, 119-121.

8. Zhang, S.Y.; Wang, B.M.; Chen, Y.G. Study on Problem of Driven Pile Floating for PHC Pile in Cohesive Soil. Electr. Power Surv. Des. 2009, 4, 19-25.

9. Bakroon, M.; Daryaei, R.; Aubram, D.; Rackwitz, F. Numerical evaluation of buckling in steel pipe piles during vibratory installation. Soil Dyn. Earthq. Eng. 2019, 122, 327-336. [CrossRef]

10. Malik, A.A.; Kuwano, J.; Tachibana, S.; Maejima, T. End bearing capacity comparison of screw pile with straight pipe pile under similar ground conditions. Acta Geotech. 2017, 12, 415-428. [CrossRef]

11. Abu-Farsakh, M.Y.; Haque, M.N.; Tsai, C. A full-scale field study for performance evaluation of axially loaded large-diameter cylinder piles with pipe piles and PSC piles. Acta Geotech. 2017, 12, 753-772. [CrossRef]

12. Paik, K.; Salgado, R. Effect of pile installation method on pipe pile behavior in sands. Geotech. Test. J. 2004, 27, 78-88. [CrossRef]

13. Saleem, M.A.; Malik, A.A.; Kuwano, J. End shape and rotation effect on steel pipe pile installation effort and bearing resistance. Geomech. Eng. 2020, 23, 523-533.

14. Han, F.; Eshan, G.; Monica, P.; Rodrigo, S.; Mir, Z. Axial resistance of open-ended pipe pile driven in gravelly sand. Géotechnique 2020, 70, 138-152. [CrossRef]

15. Ganju, E.; Han, F.; Prezzi, M.; Salgado, R. Static capacity of closed-ended pipe pile driven in gravelly sand. J. Geotech. Geoenvironmental Eng. 2020, 146, 04020008. [CrossRef]

16. Bradshaw, A.S.; Haffke, S.; Baxter, C.D.P. Load transfer curves from a large-diameter pipe pile in silty soil. In Full-Scale Testing and Foundation Design, Honoring Bengt H, Fellenius; ASCE: Reston, VA, USA, 2012; pp. 590-601.

17. Yu, F.; Yang, J. Improved evaluation of interface friction on steel pipe pile in sand. J. Perform. Constr. Facil. 2012, 26, 170-179. [CrossRef]

18. Igoe, D.; Gavin, K.; O'Kelly, B. Field tests using an instrumented model pipe pile in sand. In Proceedings of the 7th International Conference on Physical Modelling in Geotechnics, Zurich, Switzerland, 28 June 2010.

19. Gavin, K.G.; Lehane, B.M. The shaft capacity of pipe piles in sand. Can. Geotech. J. 2003, 40, 36-45. [CrossRef]

20. Ko, J.; Jeong, S.; Lee, J.K. Large deformation FE analysis of driven steel pipe piles with soil plugging. Comput. Geotech. 2016, 71, 82-97. [CrossRef] 
21. Chow, F.C.; Jardine, R.J.; Brucy, F.; Nauroy, J.F. Effects of time on capacity of pipe piles in dense marine sand. J. Geotech. Geoenviron. Eng. 1998, 124, 254-264. [CrossRef]

22. Zhang, M.; LIU, J.; YU, X. Field test study of time effect on ultimate bearing capacity of jacked pipe pile in soft clay. Rock Soil Mech. 2009, 30, 3005-3008.

23. Feng, H.; Dai, X.; Chen, S.; Chen, J. Research on Bearing Characteristics of Open-Ended Pipe Piles under Static Load. Adv. Civ. Eng. 2021, 2021, 5572898. [CrossRef]

24. Jia, H.; Lan, X.; Zheng, S.; Li, L.; Liu, C. Assessment on required separation length between adjacent bridge segments to avoid pounding. Soil Dyn. Earthq. Eng. 2019, 120, 398-407. [CrossRef]

25. SHI, F. Experimental research on load transfer mechanism of pretensioned high strength spun concrete piles. Chin. J. Geotech. Eng. 2004, 1, 95-99.

26. Lu, W.T.; Wang, Y.H.; Leng, W.M. Testing and numerical analysis of load transfer mechanism of PHC pile. Rock Soil Mech. 2006, $27,466-470$.

27. JTG/T 3512-2020. Technical Specification for Foundation Piles Testing of Highway Engineering; Standards Press: Beijing, China, 2020.

28. Zhussupbekov, A.; Shin, E.C.; Shakhmov, Z.; Tleulenova, G. Experimental study of model pile foundations in seasonally freezing soil ground. Int. J. 2018, 15, 85-90. [CrossRef]

29. Aldaeef, A.A.; Rayhani, M.T. Interface shear strength characteristics of steel piles in frozen clay under varying exposure temperature. Soils Found. 2019, 59, 2110-2124. [CrossRef]

30. Wang, X.N. Research of Bored Pile Vertical Carrying Capacity in Permafrost Region. Master's Thesis, Northeast Forestry University, Harbin, China, 2005.

31. Xu, C.H. Research on Axial Bearing Behavior of Cast-in-Place Concrete Pile in Permafrost Region. Ph.D. Thesis, Harbin Institute of Technology, Harbin, China, 2009. 